\title{
COMMUNITY PARTICIPATION IN ROSELA WASTE BANK DURING THE COVID-19 PANDEMIC
}

\author{
Purnomosutji Dyah PRINAJATI ${ }^{*}$, and Linda NOVIANA \\ Environmental Engineering, Sahid University Jakarta, Indonesia \\ *iinsoekandar@gmail.com
}

\begin{abstract}
The purpose of this activity is to improve the economy and environmental sustainability, create public awareness in waste management, namely the Rosela Waste Bank in Pangkalanjati Baru Village, Cinere District, Depok City, West Java Province. So far, the community has run a waste collection business with the Garbage Bank system obtained from waste in the environment, it has been going well, even the community in depositing waste has been segregated. The problem faced by the Rosela Garbage Bank is that human resources are inadequate to be able to manage the generation of waste generated from household waste which is getting higher with the Covid-19 pandemic, the community is more consumptive so that the generation of high waste needs the innovation that supports waste management, thereby reducing the pollution load. The solutions for this program are (1) Creating public awareness in managing waste. (2) Instilling public awareness in managing waste. (3) Creating opportunities in waste management to increase the family economy. (4) Creating innovations that are easy to implement in managing waste. (5) Application of appropriate technology in managing sustainable waste.The program target to be achieved in this activity plan for the two partners is to increase public knowledge about waste management with the waste bank system by up to $90 \%$. Community skills to manage waste up to $60 \%$. The economic aspect of the community with the additional income from the waste bank is up to $40 \%$. To ensure the success of the program, the evaluation will be carried out at every stage of program development and after the waste bank is operational, it will continue to be monitored and facilitated so that it will continue to develop through several programs that can be accessed from both internal and external communities.
\end{abstract}

Keywords: Participation, Waste Bank, Covid-19 Pandemic

\section{BACKGROUND}

Pangkalanjati Baru Village is one of the villages located in Cinere District, Depok City, where the village is located in a densely populated area from simple settlements to luxury settlements separated by toll roads, where people produce a lot of waste, this area is also close to the industry so a lot of merchants. Based on population administration data, the population of Pangkalanjati Baru Village has a population of 7,096 people, the population in Cinere District always changes every month, this is influenced by several factors, namely the existence of Births, Deaths, and Population Migration. so that Pangkalanjati Baru Village has a fairly high population density, thus the amount of waste generated is high. To reduce the amount of waste, especially waste generated from household activities, it is necessary to manage waste with a waste bank system.

The problem faced by the community is that more and more waste generation will certainly affect the environmental quality of Pangkalanjati Baru Village because there is still a lack of Human Resources who will manage the waste bank which has been running since 2015 where the Rosela waste bank has been running well and the people who are become a customer of the Rosella Waste Bank, sort the waste first and then deposit it. Nowadays, the operation of the Rosella Waste Bank is in dire need of more efficient and effective management to manage waste better, it is necessary to evaluate human resources to improve the quality of this Rosella waste bank. Appropriate technology as an innovation in waste management to reduce the problems faced by the Rosela Waste Bank. With the existence of the Rosella Garbage Bank in Pangkalajati Baru Village, it is necessary to have appropriate technology with a strategic location on the outskirts of DKI Jakarta City as a fringe buffer area and equipped with luxury settlements and infrastructure facilities.

A city is a geographical area where some residents live with a relatively high population density, whose main activity is in the non-agricultural sector and has relatively better infrastructure and facilities compared to the surrounding area.

The main categories of building use consisting of residential, commercial, industrial, government, transportation are elements that form the pattern of urban land use. Apart from being composed of buildings as described above, the city also contains other structures or buildings that are not buildings, namely: bridges, electrical substations, oil refineries, and various other installations that are not commonly referred to as buildings, because of the structure of the building. not like buildings in general in terms of covering the ground underneath. Structures that are not buildings also have important functions for a city, as do buildings. Cities are also composed of utility networks that are below ground level. The buildings above, whether used for residential, commercial, industrial, government or transportation will be connected to the existing underground public utility network such as clean water networks, telephone cables, sewage treatment lines, reservoirs, culverts, drains irrigation, and flood control.

Socially cities can be seen as communities that were created initially to increase productivity, through concentration and specialization of the workforce and allow for the diversity of intellectual, cultural, and recreational activities in cities. An area is called a city if the area can provide the needs/services needed by residents in the community.

In principle, the sourcing approach requires the reduction of waste products that will be sent to the final 
processing site. Ways that can be taken to reduce waste include sorting waste and applying the 3R principle (Reduce, Reuse, Recycle) or reduce, reuse and recycle waste (Syarifudin, 2004)

Article 16 of Law No. 23/1997 on the Environment mandates that the community is responsible as a producer of waste generation. It is hoped that the community as a source of generation that is at risk as a source of pollution, is expected to participate in the waste management system.

\section{METHOD}

\section{Approach Method}

Based on the problems that have been described previously and the agreement between the proposing team and partners, the solutions offered to overcome the existing problems can be done using the following approach methods:

1. Initial socialization, providing an introduction and basic knowledge about the waste bank to the public.

2. Technical training, follow-up meetings by providing detailed explanations on the standardization of the waste bank system, the working mechanism of the waste bank, and the advantages of the waste bank system.

3. Implementation of the waste bank system, checking the readiness of the waste bank operation

4. Monitoring and evaluation, assisting so that the waste bank is managed properly

5. Development, expanding the waste bank based on the results of monitoring and evaluation.

\section{Work Procedure}

To support the realization of the methods offered, the working procedures of the Community Service activities for waste management with the waste bank system can be detailed as follows:

1. Carry out training/assistance activities for motivational resources

2. Carry out providing a detailed explanation of the standardization of the waste bank system, the working mechanism of the waste bank, the advantages of the waste bank system.

\section{Action Plan}

To implement the empowerment method, the stages of empowerment activities are carried out with the following steps:

1. The first stage, collects data, facts, and information related to the problem of the object of community service.

2. The second stage is to develop a joint plan through a focused discussion approach. In this process, all stakeholders are involved. The purpose of this discussion is to get support and agree on solutions to problems together.

3. The third stage is to draw up a work plan. The results of the focused discussion are included in the strategic plan matrix tables. The matrix will describe the objectives of the activity, location, scope, roles of related parties, required cost plans, indicators of success, and postmentoring sustainability processes.

4. The fourth stage, the technical implementation plan which contains a detailed timetable in a large table. It is hoped that all interested parties know the plan to be carried out. In this way, all resources are involved in the management process which includes: planning, organizing, reporting, and monitoring.

5. The fifth stage is the implementation of activities that have been planned and agreed upon with partners.

6. The sixth stage, monitoring evaluation, and report generation. At this stage the dissemination of the results of the implementation is also carried out, so that a thorough evaluation can be carried out, discussing sustainability, and development efforts. Dissemination is also intended to provide a learning process for other activities. All subsequent activities are published in the form of scientific articles at the national level, thus indirectly promoting the efforts of partners.

\section{RESULTS AND DISCUSSION}

\section{Community Participation in Waste Banks}

Pangkalanjati Baru Village is a village located in Cinere District, Depok City, West Java, which is densely populated, the neighborhood is divided into two segments, namely upper middle class and lower middle class. This Community Service activity was carried out by a Lecturer of the Faculty of Engineering with the Environmental Engineering Study Program, Sahid University, Jakarta, it takes the middle to lower segment of society who need attention from the government for their environmental conditions. The people of Pangkalanjati Baru Village who are members of the Rosela Waste Bank customers increase every year.

\section{Table 1. Number of Rosela Waste Bank Customers}

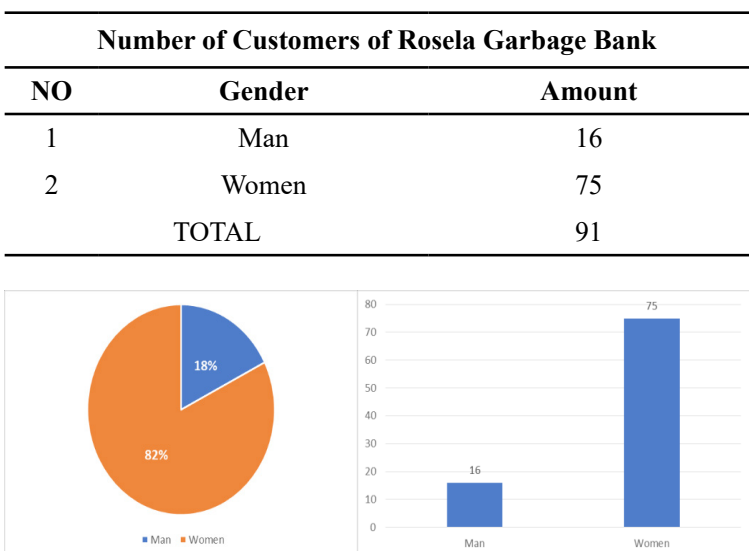

Figure 2. Graph of the Number of Rosela Waste Bank Customers

In table 1, the number of Rosela Waste Bank customers is 91 community members spread across Pangkalanjati Baru Village which consists of $16(18 \%)$ male customer members and $75(82 \%)$ female customer 
members. The number of customer members is more women because they have more time at home and even the majority are housekeepers and trade at home, so there is a great opportunity to become a customer of Rosela's waste bank. The level of community participation is very high with the Rosela waste bank.

\section{Types and Handling}

The type of inorganic waste handling in Pangkalanjati Baru Village, Cinere District, Depok City, is carried out at the Rosela Waste Bank by sorting the waste first before sending it to the Rosela waste bank. This is done to make it easier for Rosela Waste Bank officers due to limited human resources. And for people who do not participate in the Waste Bank activities, the handling of inorganic waste is the same as organic waste, which is transported by a unit (waste transport) every Sunday, recording the amount of waste in the tube by weighing the waste and then recording it in the waste savings book. Rosela Waste Bank accepts customers to save their waste every second and fourth week of the month and serves the community from 09.00 -12.00. People who cannot deposit their waste will be taken by officers to the residents' homes.

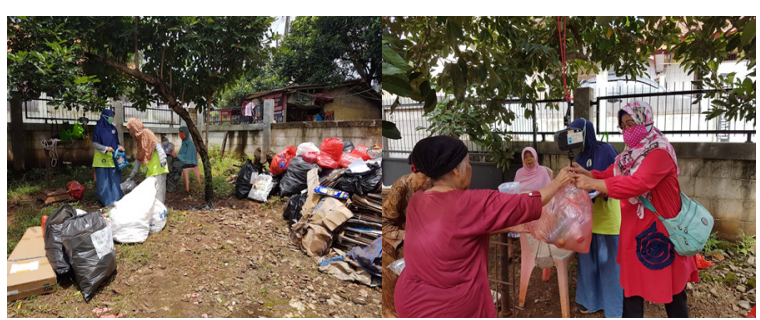

Figure 3. Waste depositing and weighing activities

The Rosela Garbage Bank only accepts waste from the community of Pangkalanjati Baru Village, which is an inorganic waste because it has a fairly high selling value. Organic waste has not been processed by the Rosela Waste Bank. The types of waste deposited by the people of Pangkalanjati Baru Village are shown in Table 2.

Table 2. Price List of Inorganic Waste at Rosella Waste Bank

\begin{tabular}{llr}
\hline No & \multicolumn{1}{c}{ NAME OF GOODS } & PRICE Rp/Kg \\
\hline 1 & Then & 1,080 \\
2 & White & 1,260 \\
3 & Newspaper & 900 \\
4 & Magazine & 540 \\
5 & Duplex Book & 270 \\
6 & Book & 900 \\
7 & Glass A & 4,050 \\
8 & Glass B & 2,500 \\
9 & Bottle A & 2,250 \\
10 & Bottle B & 1,500 \\
11 & Crystal & 2,250 \\
12 & Paralon & 900 \\
13 & Mixture & 1,080 \\
14 & Crackle & 270 \\
15 & Carpet & 720 \\
16 & Shoe & 180 \\
17 & Cable & 2,250 \\
\hline
\end{tabular}

\begin{tabular}{llr}
\hline No & \multicolumn{1}{c}{ NAME OF GOODS } & PRICE Rp/Kg \\
\hline 18 & Iron & 2,250 \\
19 & Cans & 450 \\
20 & Aluminum & 7,200 \\
21 & Cabin & 1,350 \\
22 & Glass & 180 \\
23 & Beer Bottle & 360 \\
24 & Ps plastic & 900 \\
25 & TV & 27,000 \\
26 & Battery & 7,200 \\
27 & Bottle cap & 1,350 \\
28 & Dispenser & 36,000 \\
\hline
\end{tabular}

\section{Characteristics of Respondents}

Respondents in Community Service amounted to 91 Rosela Waste Bank customers, who were present in filling out questionnaires that we distributed directly to the customer community from the Rosela Waste Bank which was guided by the Environmental Engineering Study Program students, Sahid University Jakarta, as many as 54 customers and were residents of Pangkalanjati Baru Village, Subdistrict Cinere City Depok. The characteristics of Rosela Waste Bank customers are more dominant. Older women are housekeepers and traders at home and they have more time at home so they can collect their waste.

Table 3. Questionnaire for Rosela Waste Bank Customers

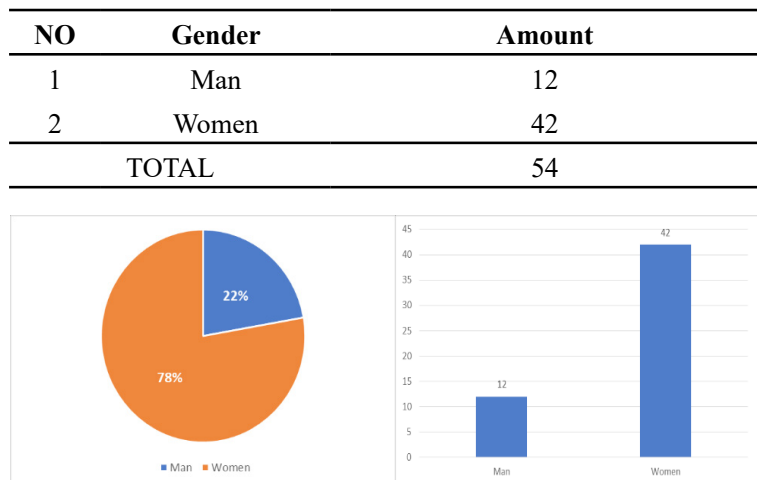

Figure 4. Number of Rosela Waste Bank Customers who filled out the Questionnaire

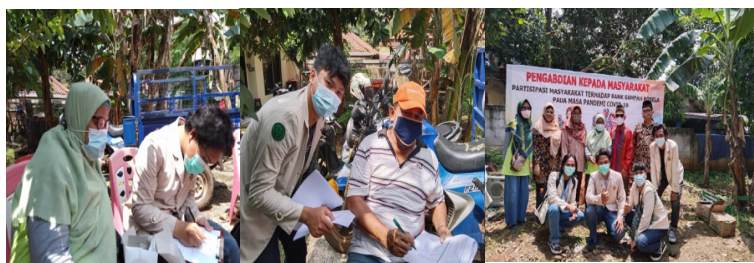

Figure 5. Filling out questionnaires guided by students

Of the 91 customers of the Rosela Waste Bank who filled out questionnaires in the Focus Group Discussion (FGD) meeting, 54 customers filled out the questionnaire consisting of 12 men and 42 women. Those who were presentweremostlywomen, in thisFocus GroupDiscussion (FGD) meeting, it was indeed limited considering that it was still during the COVID-19 pandemic, as a form of obedience to Government Regulations, namely Using Masks, Keeping Your Distance, Washing Hands, and Avoiding Crowds. Customers who attended the Focus 
Group Discussion (FGD) prioritized the Rosela Waste Bank Management, stakeholders from the Pangkalanjati Baru District and Urban Village, and representatives from the community that had been determined at previous meetings.

\section{Rosella Waste Bank Stability}

The number of waste bank customers, the stability of the waste bank is seen from the customer-aspect which is increasing every year. The Rosela Garbage Bank was established in 2015 at that time the number of new customers reached 55 only those who routinely deposited their waste around 32 customers then the officers carried out activities by inviting the people of Pangkalanjati Baru Village, Cinere District, Depok City to participate in the Rosela Waste Bank activity. Until 2019, the number of customers continued to increase with various efforts made by the Rosela Waste Bank Manager. According to the Chairperson of the Rosela Waste Bank, this figure is far from being effective, considering the number of families in Pangkalanjati Baru Village, Cinere Sub-district, the Chairperson of the Rosela Waste Bank and other officers is seeking various ways so that all communities can play an active role in the Rosela Waste Bank program. Because the Rosela Waste Bank program is very helpful in reducing the waste problem in Pangkalanjati Baru Village in particular.

Table 4. Number of Waste Bank Customers Increase Every Year

\begin{tabular}{cccc}
\hline NO & YEAR & $\begin{array}{c}\text { NUMBER OF } \\
\text { CUSTOMERS }\end{array}$ & ACTIVE CUSTOMER \\
\hline 1 & 2015 & 55 & 32 \\
2 & 2016 & 55 & 32 \\
3 & 2017 & 65 & 46 \\
4 & 2018 & 75 & 54 \\
5 & 2019 & 91 & 78 \\
6 & 2020 & 91 & 83 \\
\hline
\end{tabular}

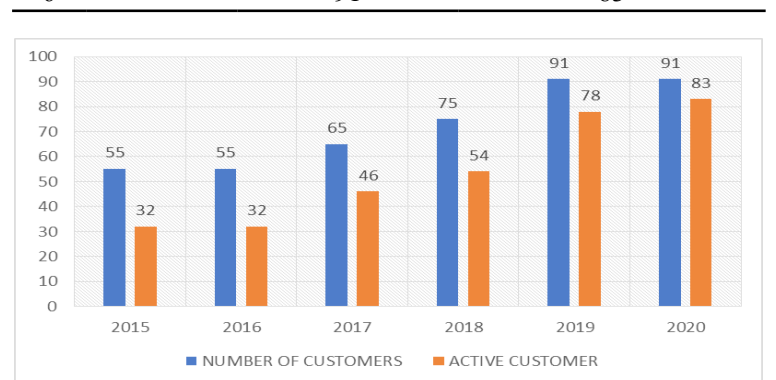

Figure 6. Graph Number of Waste Bank Customers Increase Every Year

Since the establishment of the Rosela Waste Bank in 2015, there has been a non-significant increase, only continuing to manage the Waste Bank. During the Covid-19 pandemic, there was a significant increase. After we made observations in the field, the existence of the Rosela Waste Bank was very effective. During the covid-19 pandemic, which occurred in 2019, Rosela Waste Bank customers increased along with the increasing number of consumptive people because people who used to work underwent Work From Home (WFH) where 75\% of the people were active at home, this was also a trigger for the high rate of generation. trash. The generation of waste that has increased sharply is waste from households, food stalls, cafes, futsal, and other entertainment venues which are completely closed, even though so far the most waste is from these places.

\section{CONCLUSIONS AND SUGGESTIONS Conclusion}

In Community Service activities in Pangkalanjati Baru Village, Cinere District, Depok City, resulted in:

1. Community Participation in the Rosela Waste Bank. The number of Rosela Waste Bank customers is 91 community members spread across Pangkalanjati Baru Village which consists of $16(18 \%)$ male customer members and 75 (82\%) female customer members.

2. Types and Handling. The type of handling of inorganic waste in Pangkalanjati Baru Village, Cinere District, Depok City, is carried out at the Rosela Waste Bank by sorting the waste first before depositing it into the Rosela waste bank. This is done to make it easier for Rosela Waste Bank officers due to limited human resources.

3. Characteristics of Respondents. Of the 91 customers of the Rosela Waste Bank who filled out questionnaires in the Focus Group Discussion (FGD) meeting, 54 customers filled out the questionnaire consisting of 12 men and 42 women. Those who were present were mostly women, in this Focus Group Discussion (FGD) meeting, it was indeed limited considering that it was still during the COVID-19 pandemic, as a form of obedience to Government Regulations.

4. Rosela Waste Bank Stability. In 2019, the number of customers continued to increase with various efforts made by the Rosela Waste Bank Manager. According to the Chairperson of the Rosela Waste Bank, this figure is far from being effective, considering the number of families in Pangkalanjati Baru Village, Cinere Subdistrict, the Chairperson of the Rosela Waste Bank and other officers is seeking various ways so that all communities can play an active role in the Rosela Waste Bank program. Because the Rosela Waste Bank program is very helpful in reducing the waste problem in Pangkalanjati Baru Village in particular.

\section{Suggestion}

1. The processing of organic waste from household waste is made into compost as a plant medium.

2. The existence of greenery in every yard of the house with a vertical garden system to take advantage of the narrow land.

3. Processing waste into environmentally friendly raw materials.

\section{ACKNOWLEDGMENT}

The Community Service activity with the title Community Participation in the Rosela Waste Bank during the 
Covid-19 Pandemic in Pangkalanjati Baru Village has just been carried out with an Internal Grant from LPPM Sahid University Jakarta.

\section{REFERENCES}

Achmadi, Umar Fahmi. 2014). Kesehatan Masyarakat: Teori dan Aplikasi. Rajawali Pers, Jakarta.

David, Fred R. (2004). Manajemen Strategis Konsep. Jakarta: PT Indeks Kelompok Gramedia

Hunger, J. David dan Thomas. Wheelen. (2003). Manajemen Strategis. Yogyakarta: Andi

Kementrian Lingkungan Hidup (2008). Undang-undang Nomor 18 Tahun 2008, tentang Pengolahan Sampah, Jakarta.

Marimin. (2005). Teknik dan Aplikasi: Pengambilan Keputusan Kriteria Majemuk. PT. Grasindo, Jakarta.

Menteri Pekerjaan Umum Republik Indonesia, (2003). Revisi Standar Nasional Indonesia (SNI) 03 - 3242 1994 tentang Pengelolaan Sampah di Permukiman, Jakarta

Menteri Pekerjaan Umum Republik Indonesia (2006). Peraturan Menteri Pekerjaan Umum Nomor 21/
PRT/M/2006 tentang Kebijakan dan Strategi Nasional Pengembangan Sistem Pengelolaan Persampahan, Jakarta

Mubarak, Wahit Iqbal.(2012). IlmuKesehatan Masyarakat: Konsep dan Aplikasi dalam Kebidanan. Salemba Medika, Jakarta.

LP3B Buleleng-Clean Up Bali.(2003). Sistem Pengelolaan Sampah Berbasis pada Masyarakat, USAID, Jakarta

Syaiful (2015). Strategi Pengelolaan Sampah Oleh Dinas Kebersihan Pertamanan Dan Pemakaman (DKPP) Di Kabupaten Tangerang, Tangerang

Syarifudin. (2004). Model Pengelolaan Sampah Berbasis Masyarakat(KajianAwal Untuk Kasus Kota Semarang), Makalah pada Diskusi Interaktif: Pengelolaan Sampah Perkotaan Secara Terpadu, UNDIP, Semarang.

Wulandari, Riska P. (2013). Analisis Partisipasi Masyarakat dan Kepemimpinan Terhadap Tingkat Keberhasilan Proyek Program Nasional Pemberdayaan Masyarakat (PNPM) Mandiri Perdesaan Di Kecamatan Gerokgak, Buleleng. Tesis. Universitas Udayana Denpasar, Bali. 